\title{
Education game based on timor local wisdom as an android-based mathematics learning media
}

\author{
Sulasri Suddin ${ }^{*}$, Yohanis Ndapa Deda ${ }^{1}$ \\ ${ }^{1}$ Faculty of Science Education, Universitas Timor, Indonesia \\ $\square$ sulasri.suddin@gmail.com
}

\section{Article Information}

Submitted August 04, 2020

Revised September 08, 2020

Accepted October 20, 2020

Keywords

Android;

Game Education;

Learning Media;

Timor Local Wisdom.

\begin{abstract}
The linkage of technology in the world of education today has developed rapidly. One of them is the development of mathematics learning media in the form of educational games. The purpose of this research is to develop an educational learning media game that is integrated into Timor local wisdom so that this media has its uniqueness to help students learn. Research on a fast educational game on mathematics based on an android smartphone was conducted at MTs Nurul Falah, Kefamenanu, NTT. The media was developed using software construct 2 . The method used in this research is development research with the ADDIE development model (Analysis, Design, Development, Implementation, and Evaluation). The results of the validity test based on material experts, media experts, and teachers indicate that educational games with the theme of local wisdom as android-based mathematics learning media were included in the category of very feasible to use with an average validation of 4.33 and very feasible criteria. At this stage, a limited trial using a questionnaire showed that game education received a positive response to the use of game education media with an average percentage of $98.93 \%$. These results indicate that the process of learning mathematics using this media can motivate and facilitate student learning compared to the learning that has been done. During the pandemic, COVID-19 media can be used as onlinebased learning media because students can easily download the application then the teacher controls the process.
\end{abstract}

\section{INTRODUCTION}

Trends in International Mathematics and Science Study (TIMSS) is carried out routinely every 4 years, since 1995. Indonesia is one of the countries that became TIMSS objects in the last four periods. Talking about mathematics achievement, Indonesia's position is still below the international level as reported by TIMSS. The results of the 2015 TIMSS study, Indonesia was ranked 44 out of 49 participating countries with an average score of 397 , while the average international score was 500 (Mullis et al., 2015).

The results of PISA serve as an early warning for a shift in the paradigm of education in Indonesia. The results of the PISA test for Indonesia indicate uneven reading, math, and science skills. Several Indonesian students assumed that mathematics is one of the difficult subjects taught at school. Students often experience difficulties in learning mathematics such as a lack of mathematical skills, and solving mathematical problems. The average PISA score of Indonesian students has a reading literacy score of 371 compared to an average of 487 points in OECD countries. OECD countries. As for proficiency in science, it scores an average of 396 points, compared to an average of 489 points in OECD countries (OECD, 2019).

Building students' understanding of concepts in mathematics also depends on the strategies, methods, or learning approaches applied by the teacher (Hiebert \& Grouws, 2007).

How to cite

e-ISSN

Published by
Suddin, S., \& Deda, Y. N. (2020). Education game based on Timor local wisdom as an android-based mathematics learning media. Al-Jabar: Jurnal Pendidikan Matematika, 11(2), 227-246. 2540-7562.

Mathematics Education Department, UIN Raden Intan Lampung. 
Whether or not a selection of learning models will depend on the learning objectives, suitability with the learning material, the level of development of students, the ability of teachers to manage to learn and optimize existing learning resources. In this case, the teacher can utilize and develop creative and innovative learning media so that it can attract students' interest and motivation in the mathematics learning process which in the end can be achieved in class. The development of instructional media has been done a lot, both using story problems or modules or teaching books as has been done in developing media modules based on local wisdom with valid results (Ferdianto \& Setiyani, 2018).

Over time, science and technology have an important role, especially in the field of education, for example, the most recent role of science and technology in the learning process is the development of learning media 'cyber teaching' or another popular term today is elearning. The emergence of m-learning is because m-learning is unique in that students can access the subject matter, direction, and applications related to learners, whenever and wherever. Mobile software applications that can be used in m-learning include PDAs, mobile phones, laptops, and tablet PCs. The concept of m-learning has also been focused on providing virtual learning classes that allow interaction between teachers and students in schools.

Several studies have shown the development of m-learning media in the form of android. The results of the media development carried out showed that students had the highest satisfaction and positive response to the learning applications that were made (Alqahtani \& Mohammad, 2015). Media development shows that android media can attract interest and enhance students' understanding of learning (Adiwijaya, S, \& Christyono, 2015; Setyaningrum \& Waryanto, 2018; Yulia \& Silalahi, 2019). Furthermore, the development of learning media in the form of adventure games-android was also constructed for children aged 6 years to 9 years (Rahadi et al., 2016). Also, a study on mathematics learning media in the form of an Android-based Mathematics Encyclopedia on grade VIII students of SMP / MTs had also been conducted (Agustin \& Ambarawati, 2019). This media development is not only done for elementary and junior high school students but also developed for early childhood education students (PAUD) as conducted (Vitianingsih, 2016) and even higher education level (Pons et al., 2019).

Several important case studies related to the effects of using mobile tools and applications and online applications in mathematics learning at all levels of education can motivate students and get positive responses, making mathematics more fun and interactive than ordinary teaching practices or lectures or traditional methods (Drigas \& Pappas, 2015; Fabian et al., 2018; Skillen, 2015; Sung et al., 2016; Vlachopoulos \& Makri, 2017). M-learning can increase interest and motivation for parents and learners in learning mathematics and provides opportunities for various methods of teaching mathematics (Chao et al., 2018; Taleb et al., 2015) Furthermore, the existence of an interactive mobile application enables students to have plenty of time and ways to practice problem-solving outside the classroom (Figueiredo et al., 2016).

Based on the results of several previous studies, it was only limited to developing mathematics learning media in the form of game education. Therefore, the researcher intends to research the development of Android-based learning media based on local wisdom in the environment of the researchers. This is intended because so far the learning tools only contain 
theoretical theories, and only count operations in Android, without trying to build a contextualbased android media, in this case, Timor local wisdom.

Based on the things that have been described, then with the development of media Based on a survey conducted on students of Kefamenanu MTs Class VII at TTU, around 84\% of students have an android, while around the other $16 \%$ do not yet have an android smartphone. The interview results show that students only use their devices as entertainment applications such as games, music, social media (Facebook, Instagram, etc.), and so on. The development of a local culture-based education game Timor on the Android application as a medium for learning mathematics with the help of the first new Software Construct 2 was conducted in Kefamenanu. In this study, learning media that will be presented in the form of game education. The type of game education that will be designed is an adventure game, specifically creating designs and animations based on East Timor's local culture as a facility in learning mathematics as well as the introduction and preservation of Timorese local culture as the identity of the Indonesian Nation. The aspects of Timorese culture in this media are in the form of Timor traditional houses (Lopo, Ume Kbubu), several woven fabrics (Buna Motif, Futus, etc.), musical instruments, etc. which contain geometric elements so that mathematical material becomes easier to understand. This application is in the form of a moving animation that also contains audio elements which of course are focused on triangular and rectangular material. The making of this educational game will be done with the help of Software Construct 2. This Android-Based Mathematics Education Game Application aims to produce a game application that can train children or students to learn to solve contextual problems especially those with a local Timor wisdom with ease and fun so that children do not get bored with a monotonous learning method. Created in the form of mobile aims to be easy to carry anywhere. It is expected that the creation of mathematics education media based on game education can make learning pervasive and visual appearance and interaction in games are also expected to simplify and increase students' interest and motivation in the process of learning mathematics at MTs Nurul Falah Kefamenanu TTU.

\section{METHODS}

The research method that would be used in this research refers to the R\&D with ADDIE models consisting of five stages namely analysis, design, development, implementation, and evaluation which aim to develop a valid, practical, and effective mathematics learning media, in the form of game education learning media based on local culture. The use of the ADDIE model was done with the consideration that this model was suitable for developing products that are targeted, effective, and dynamic in improving the quality of learning for teachers. The steps that need to be carried out in the ADDIE model could be seen as follows. 


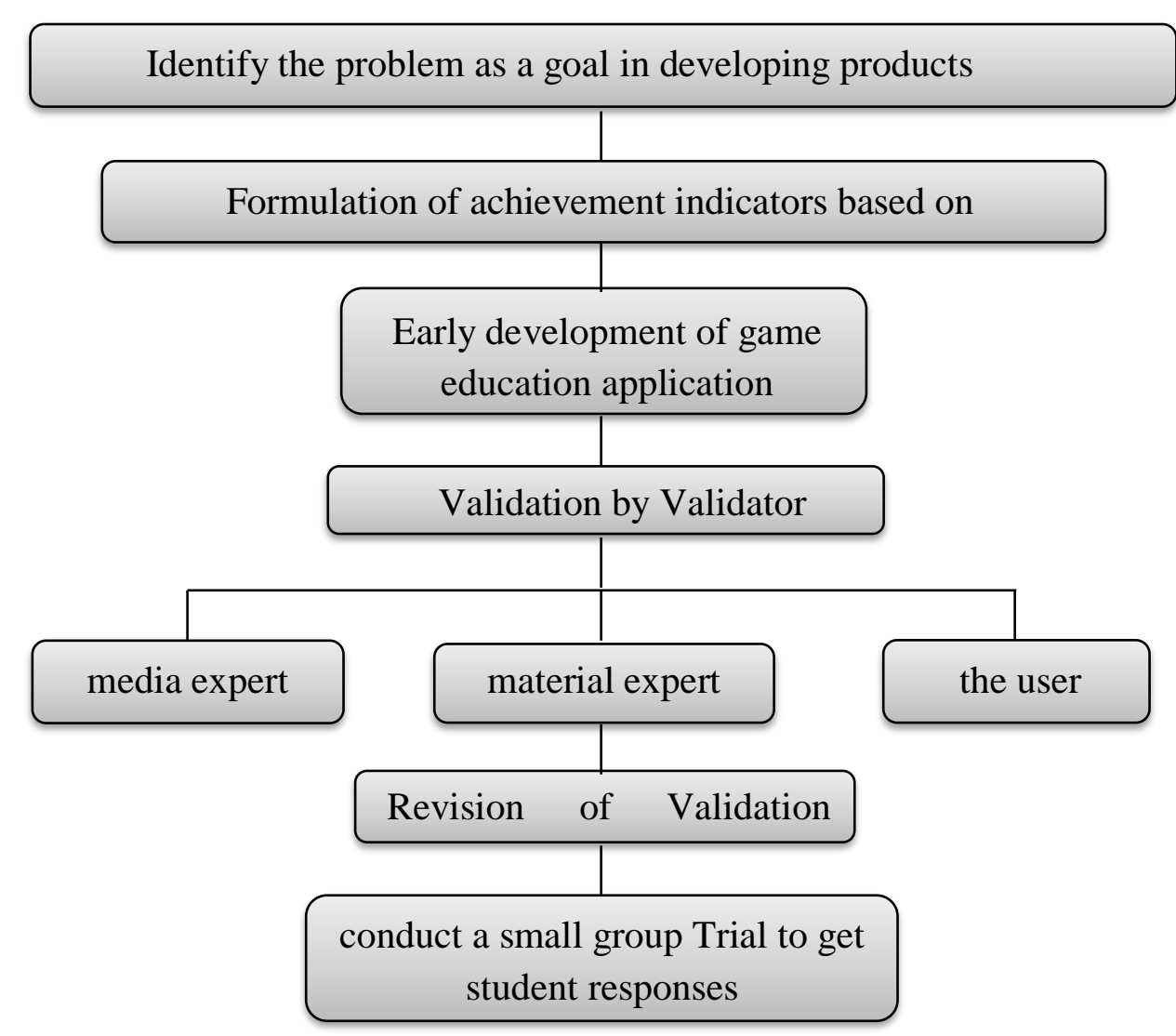

Figure 1. Educational Games as android-based mobile Learning Media for Middle School Students

The steps that must be done in the ADDIE model could be seen as follows.

a. Analysis

The analysis process could be carried out by literacy studies, namely collecting data in the form of supporting theories for learning media to be made, field studies, namely conducting interviews at schools with mathematics subject teachers and surveys of the use of Android devices in students at the school, and seeking information about technological developments that occur at MTs Nurul Falah Kefamenanu.

b. Design

In developing mathematics learning media, the design stage included determining learning objectives, designing scenarios or learning activities on the media, designing learning material designs, designing content, and designing evaluation tools to measure the multiplication of learning media, especially triangular and rectangular material.

c. Development

In this activity, researchers began to produce instructional media products in the form of educational games that can be used in Android applications with the help of Construct 2 Software.

d. Implementation

Media that had been developed in the previous stage would be implemented in users, namely teachers and students in real situations in the field. During implementation, the material presented was following the learning media that had been developed. The implementation was carried out in a small group of students consisting of 6-10 students to 
know small mistakes and the feasibility of learning media and knowing student responses to the learning media that had been developed.

e. Evaluation

At this stage, the evaluation was always carried out at every four stages in development or so-called formative evaluation. In this study only limited to formative evaluation to revise the media needs. Summative would be discussed in other writings.

To determine the quality and test the feasibility of the product or media that had been developed, several steps need to be taken as follows.

a. Validation by product experts, both media experts (visual clarity, audio, convenience, aesthetics and user needs, etc.) and material experts (material presentation, question quality, language, etc.). The purpose of expert validation was to review products, provide suggestions or improvements, and validate the product as a learning medium so that it was feasible and ready to use.

b. Validation by users/field practice by a seventh-grade math teacher at MTs Nurul Falah Kefamenanu. The purpose of validating the field practice was to see small errors that had escaped the observations of the experts (media experts and material experts) before being tested in small groups.

c. Trials were limited to small groups. Based on the analysis phase it was known that about 15 people who had androids from 21 seventh grade students of MTs Nurul Falah Kefamenanu. Furthermore, this trial was carried out on 6 students of an android smartphone with purposive sampling based on mathematical abilities (student test results), namely students with low, medium, and high abilities, as many as two students each. The goal is to find out technical errors in the form of audio, visual, and so on in-game education learning media. For field trials in large groups, a total of seventh-grade students would be carried out and will be discussed in the next paper.

Furthermore, the results of the assessment will obtain research data that will be processed. The data analysis technique used is descriptive qualitative statistics which are presented in tabular form and then interpreted as explanatory sentences.

a. Data analysis of the results of validation of learning media by experts (media and material) and users/field practitioners (teachers)

1) Input product validation data by experts and users/field practitioners into the table. Product validation data uses a Likert scale which can be seen in Table 1.

Table 1. Criteria for attitudes using the Likert scale

\begin{tabular}{cccccc}
\hline \multirow{2}{*}{$\begin{array}{c}\text { Statement } \\
\text { Response }\end{array}$} & $\begin{array}{c}\text { Strongly } \\
\text { Agree }\end{array}$ & Agree & Doubtful & Disagree & $\begin{array}{c}\text { Strongly } \\
\text { disagree }\end{array}$ \\
\hline Positive & 5 & 4 & 3 & 2 & 1 \\
\hline Negative & 1 & 2 & 3 & 4 & 5 \\
\hline
\end{tabular}

2) Determine the highest score for each validator's assessment

The highest score for each validator $=$ number of aspects assessed $\mathrm{x}$ maximum score

3) Determine the average of each validator.

Average of Each Validator $=\frac{\text { Total score of the assessment results for each validation sheets }}{\text { The highest total score for each validation sheets }}$ 
Or it can be made as a percentage.

4) Determine the average total validation.

Average Total Validity $($ ATV $)=\frac{\text { Total score of the assessment results from all validation sheets }}{\text { The highest total score of all validation sheets }}$

Or it can be made as a percentage.

5) Provide an assessment of the validity of the media with criteria as proposed (Purwanto, 2012; Widoyoko, 2009) with modifications in Table 2.

Table 2. Criteria for the Validity of M-Learning Learning Media

\begin{tabular}{ccc}
\hline Interval & Achievement $(\%)$ & Criteria \\
\hline$A T V>4,20$ & $90-100$ & Very Valid \\
\hline $3,40<A T V \leq 4,20$ & $80-89$ & Valid \\
\hline $2,60<A T V \leq 3,40$ & $65-79$ & Quite Valid \\
\hline $1,8<A T V \leq 2,60$ & $55-64$ & Less Valid \\
\hline$A T V<1,8$ & $<55$ & Not Valid \\
\hline
\end{tabular}

b. Analysis of data on student responses to learning media

Analysis of data on the results of student responses to the use of educational game learning media based on local culture used in the Android application using a scale of "Yes/Agree" and "No/Disagree". Student response data to learning with game education were analyzed by percentage $(\%)$, using the following formula:

Response value $=\frac{\text { Maximum score }}{\text { The sum of all score }} \times 100 \%$

After the percentage of student response scores is obtained, the grouping is carried out according to the criteria stated (Dasmo et al., 2017) with modifications in Table 3.

Table 3. Categories of Student Responses to Media

\begin{tabular}{cc}
\hline Achievement $(\%)$ & Criteria \\
\hline $80 \leq$ Response Value $\leq 100$ & Very Strong \\
\hline $60 \leq$ Response Value $<80$ & Strong \\
\hline $80 \leq$ Response Value $<100$ & Quite Strong \\
\hline $20 \leq$ Response Value $<40$ & Weak \\
\hline Response Value $<20$ & Very Weak \\
\hline
\end{tabular}

\section{RESULTS AND DISCUSSION}

The field study was conducted by distributing questionnaires using the Google form provided to twenty-one Android users and a grade VII mathematics teacher. The questionnaire was intended to determine student responses to the media to be applied and analysis of the learning process in class. The results of student questionnaires showed that around $93.3 \%$ of students wanted mathematics-based learning games for Android-based specifically on geometry. Meanwhile, the results of the teacher questionnaire obtained information that mathematics learning was currently not optimal. One of them was due to the use of monotonous media i.e. textbooks so that students seem passive and less interested in learning mathematics.

\section{Android-Based Educational Game Media Design Results}

The software chosen to create an android-based educational game media was Construct 2 software. Following was a diagram of the design of the concept of a fast mathematical educational game as a learning media. 


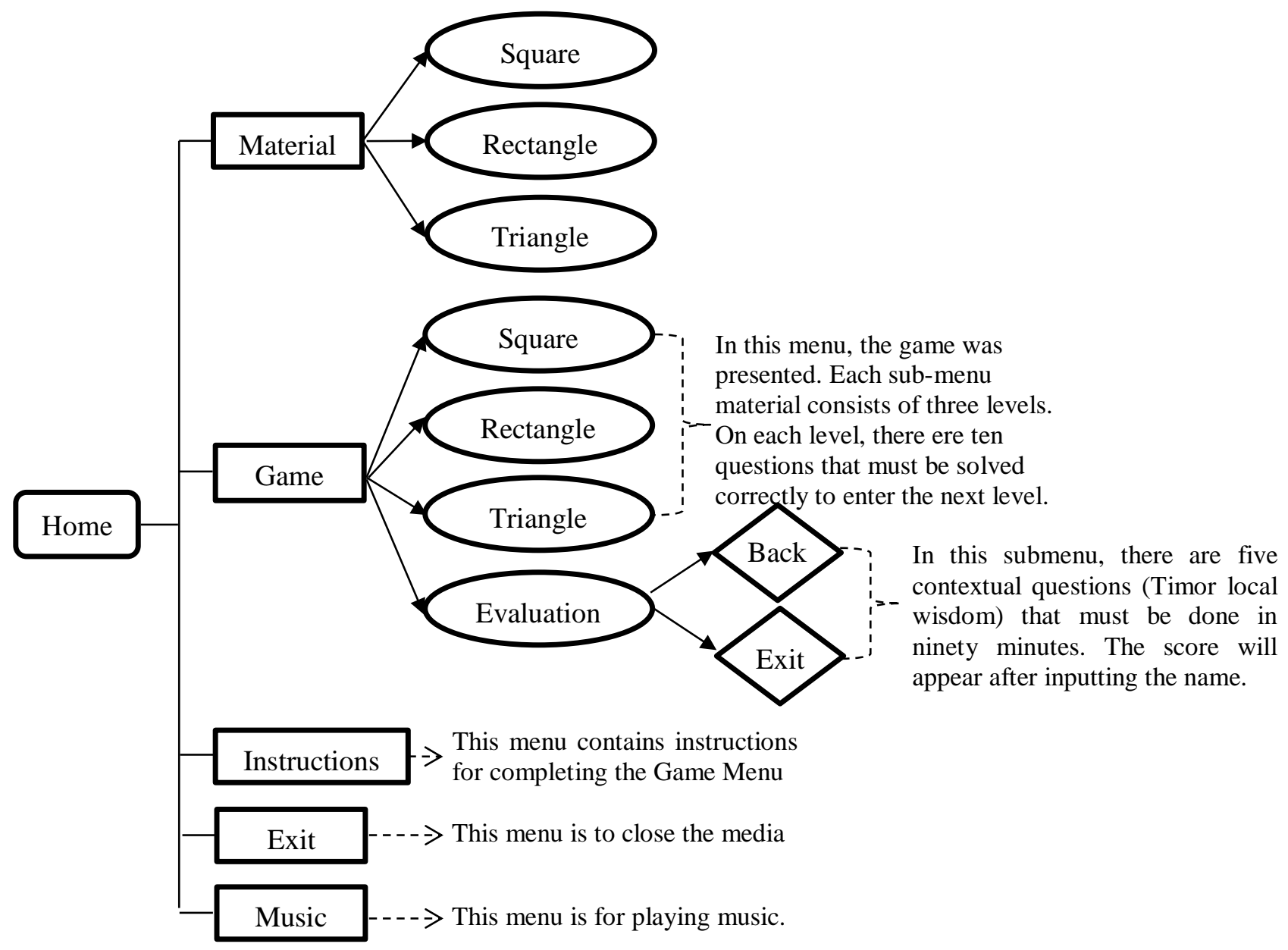

Figure 2. Educational Game Media Flowchart Results

The design of educational game learning media software developed had certain characteristics. The appearance of the design of media software that has been developed can look like the following figure.

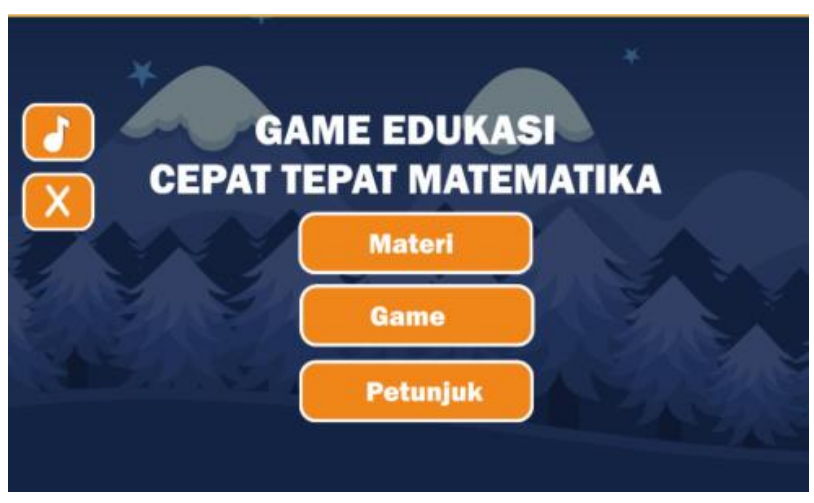

Figure 3. Display of the Main Menu

The following figure shows the start page consisting of three main menus namely the material menu, game menu, and hint menu. Then in the upper left-hand corner, there is a music menu and an exit menu symbolized by "曰 " and " $₫$ " respectively. 


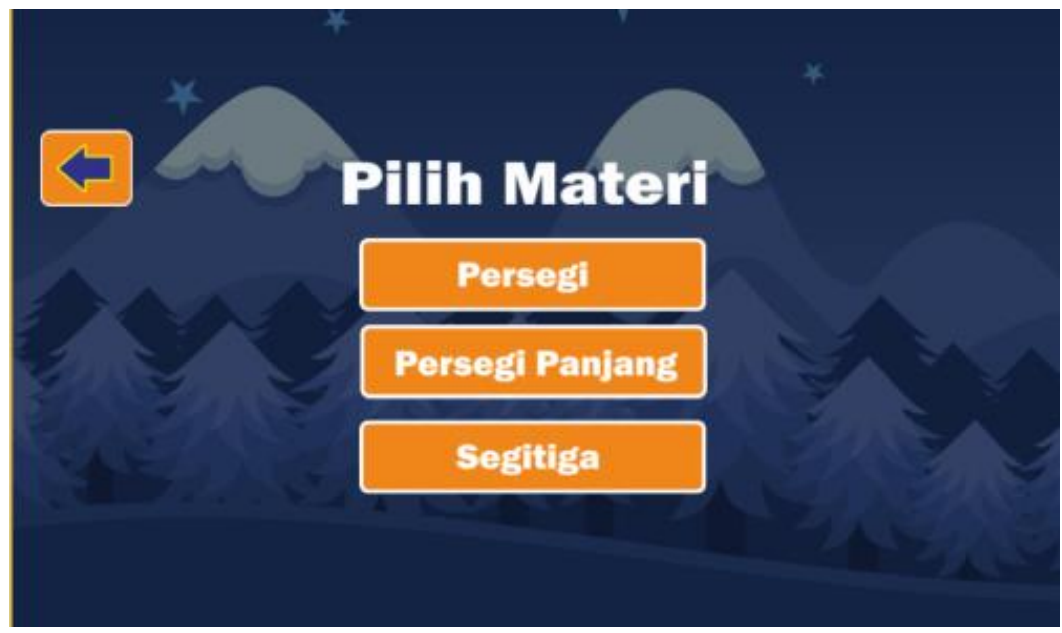

Figure 4. Display Material Menu

In the material menu, there are three submenus namely square, rectangular, and triangular. If the player wants to continue the material, click the " $\square$ " button.

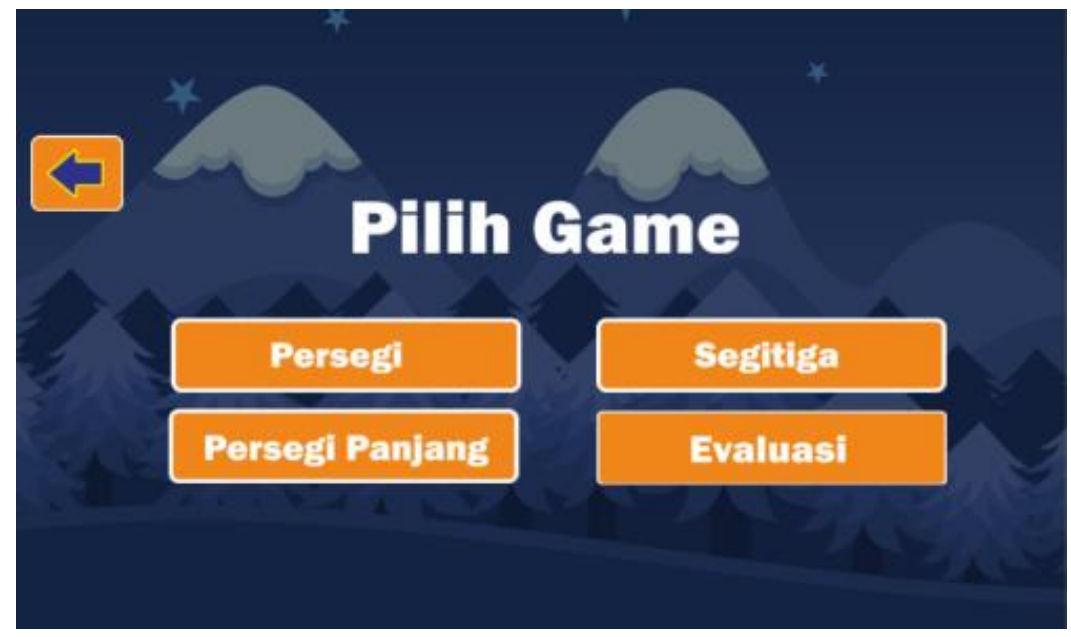

Figure 5. Display the Game Menu

On the game menu, there are four submenus namely square, rectangular, triangle, and evaluation. In the game, the menu display three sub-menus are containing the game namely square, rectangle, and triangle, each of which there are three levels.

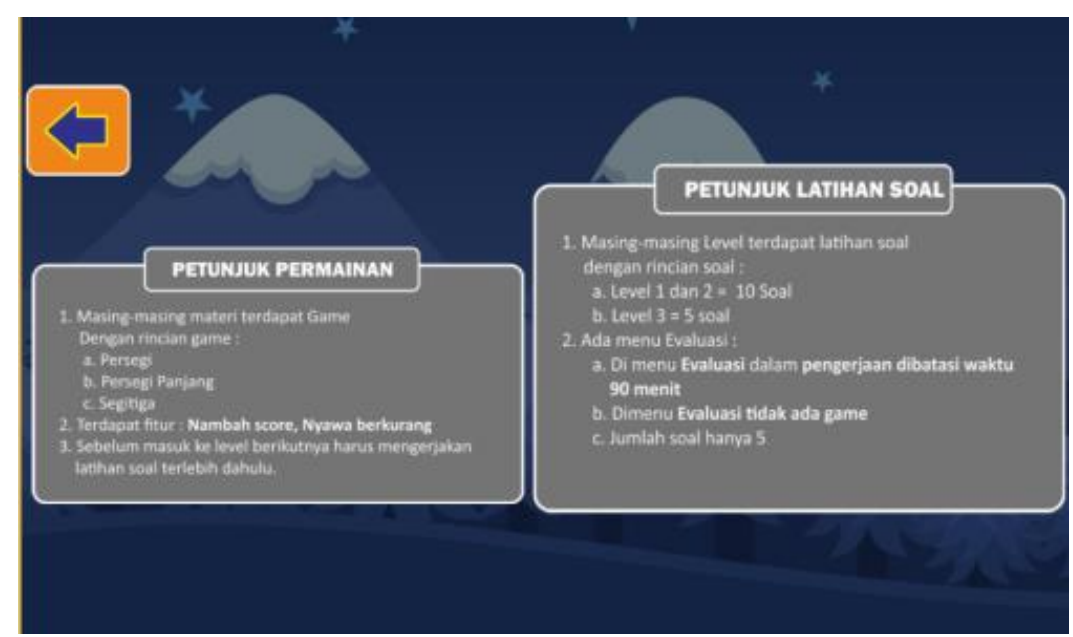

Figure 6. Display Menu Instructions 
On this menu, there are two hints namely game instructions and question work instructions (evaluation and in-game practice)

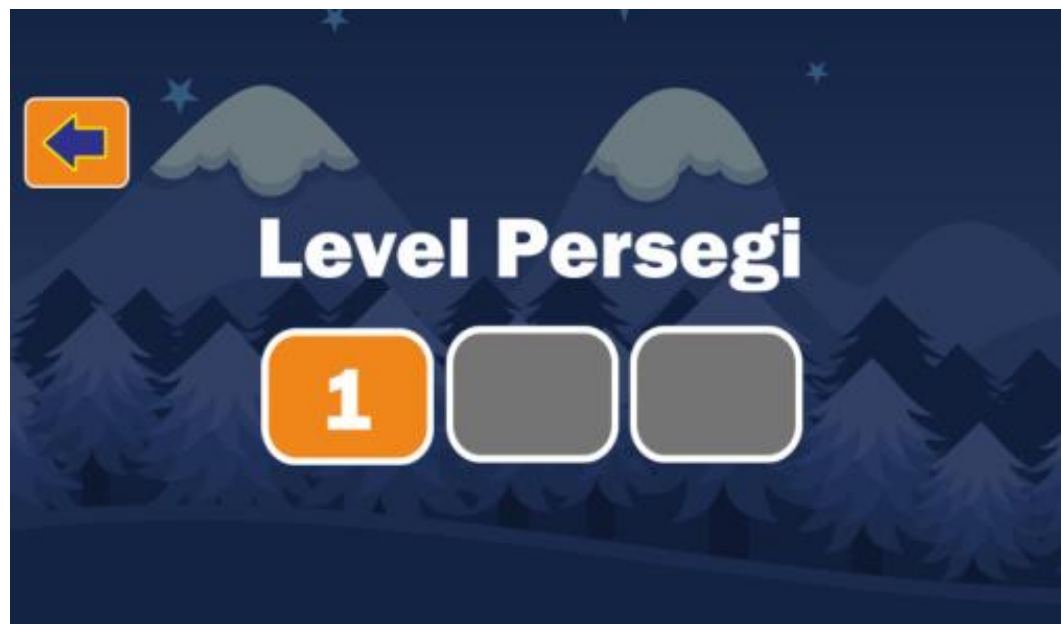

Figure 7. Display Menu Level

The following figure is a level menu consisting of three levels. The first level and the second level each have ten-question exercises that students must work on to get to the next level while the third level has five questions. The questions compiled by the researcher are adjusted to the cognitive development of junior high school students by distributing easy, medium, and difficult questions.

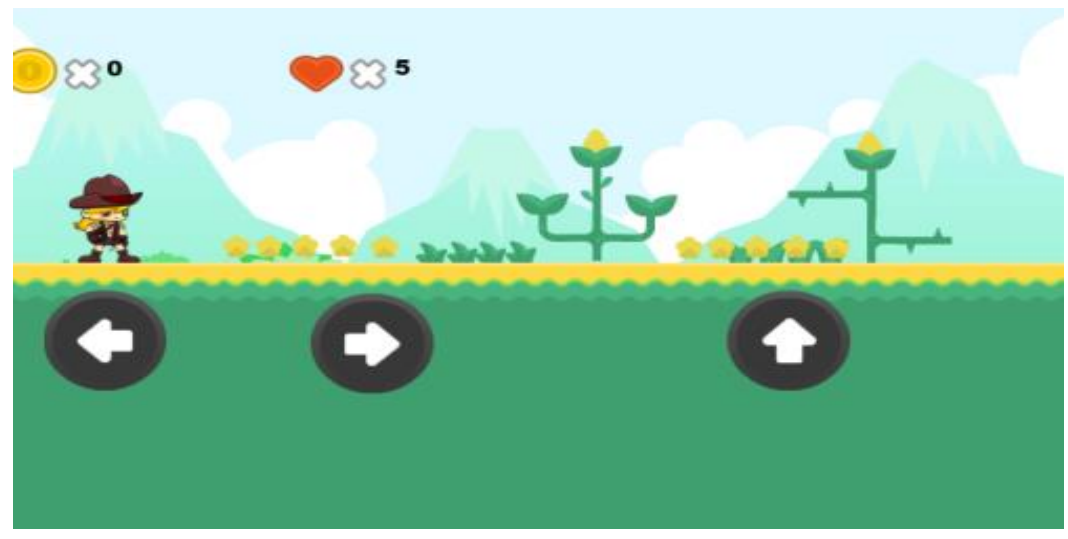

Figure 8. Game Display

Figure 8. shows the game display consisting of players, mush/mines, lives, and coins. In this game, players must collect coins but players must also avoid mines so as not to game over.

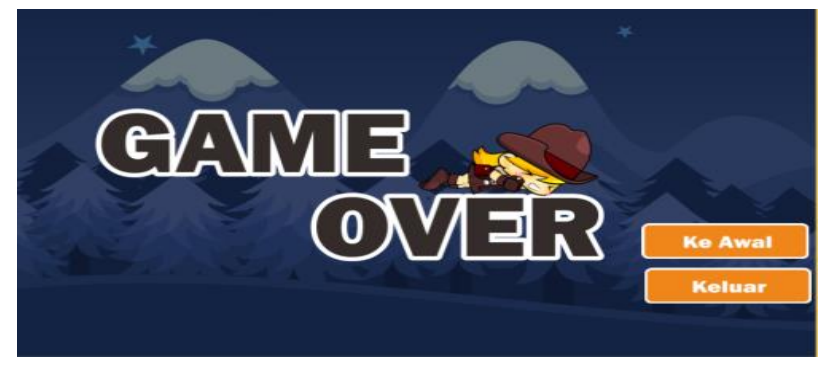

Figure 9. Game Over Display

Figure 9. shows the game finished due to the player running out of life due to landmines. 


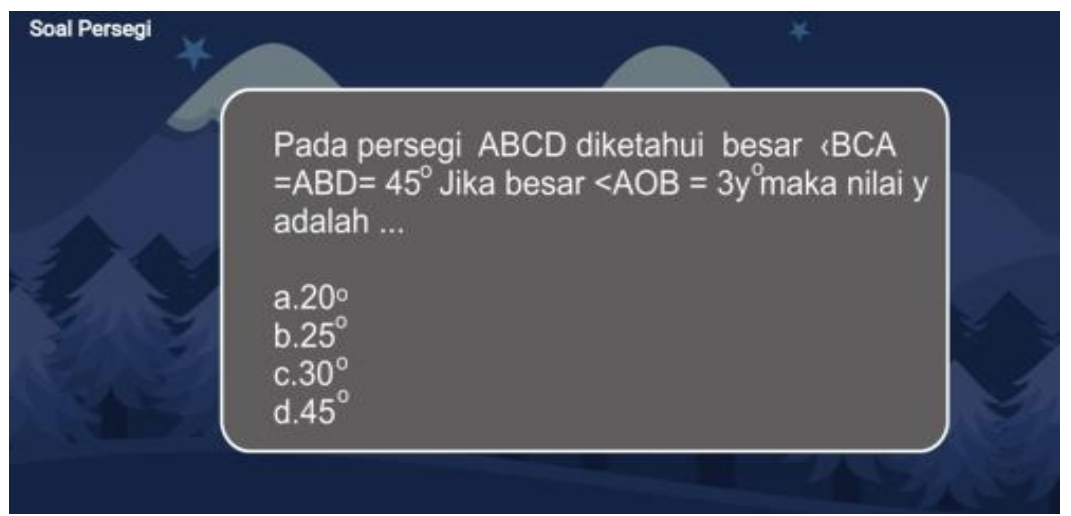

Figure 10. Display Exercise in the Game Menu

In practice in the game, ten contextual questions must be done by the player before entering the next level. The provision of this exercise is not limited in time, with the intention that students are accustomed to working on contextual problems.
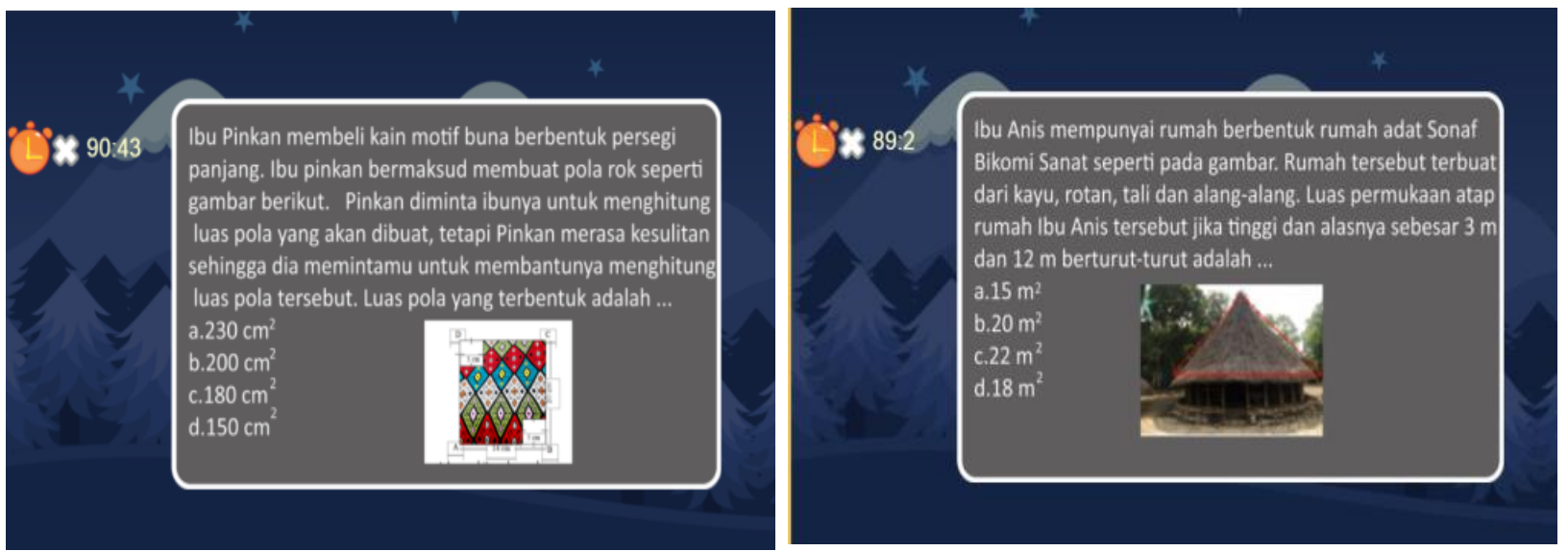

Figure 11. Evaluation Display in the Game Menu

In the evaluation menu, five questions are needed to be done by students in ninety minutes. The same evaluation questions discussing exercises in the game menu are also presented in the form of general contextual stories and local wisdom of Timor culture.
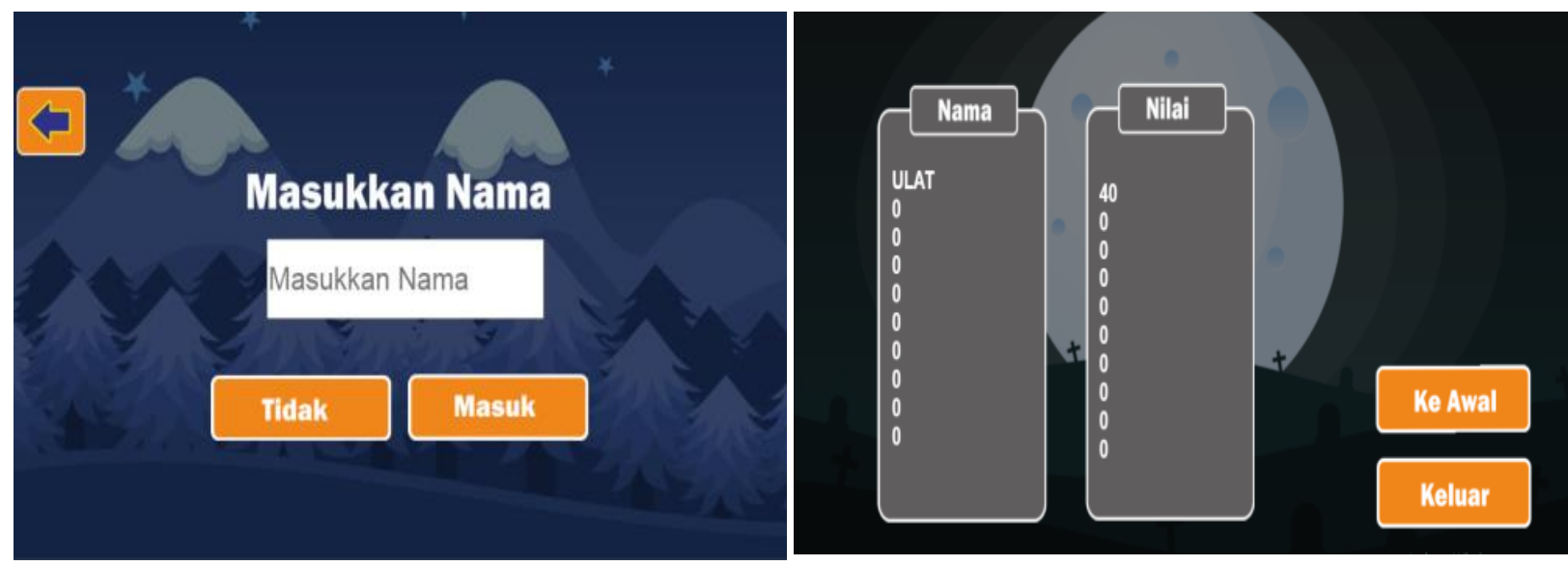

Figure 12. Display Name Filling and Display of Score Results

In Figure 12 after the evaluation is complete, the player is asked to fill in a name in the textbox then if the OK button is clicked then the score will appear. If the player clicks on the "go-to 
start" button then it will return to the main menu and "exit" then the application closes. For one android can be played by more than one student and the results of student scores will be sorted from highest to lowest. Questions that appear in random media, as well as answers to avoid bias in research.

\section{Results of Educational Game Validity as Learning Media based on Experts}

The validation process was carried out for two weeks in June by competent experts who understood the making of game media and materials as well as questions that were appropriate to the grade VII students' level and were able to provide criticism and suggestions to perfect the games that were made. Suggestions from the validator would be used as material to revise the learning media so that it could be continued. The validators selected in this study were Unimor's mathematics education lecturers and mathematics teacher of seventh grade in MTs Nurul Falah Kefamenanu.

The media expert involved in the expert examination stage was a lecturer in the mathematics education study program at the Universitas Timor. The results of the expert analysis of the media aspects can be seen in Table 4 .

Table 4. Media Game Education Expert Validation Sheet

\begin{tabular}{|c|c|c|c|}
\hline No. & $\begin{array}{c}\text { Evaluated } \\
\text { Aspects }\end{array}$ & Description & Assessment \\
\hline \multirow[t]{9}{*}{1.} & \multirow{9}{*}{$\begin{array}{l}\text { Presentation } \\
\text { of Display }\end{array}$} & The appearance of media design is presented interestingly. & 4 \\
\hline & & Media design can attract students' interest. & 5 \\
\hline & & Text/writing in-game media is easy to read. & 5 \\
\hline & & $\begin{array}{l}\text { The combination of colors and images (illustrations) chosen is appropriate } \\
\text { and attractive. }\end{array}$ & 4 \\
\hline & & $\begin{array}{l}\text { The type and size of the letters chosen are correct and make the media } \\
\text { more attractive. }\end{array}$ & 4 \\
\hline & & $\begin{array}{l}\text { Selection of the right music and sound so it does not interfere with } \\
\text { concentration when running media games. }\end{array}$ & 5 \\
\hline & & Audio and visuals on the media are presented clearly. & 5 \\
\hline & & The game flow is presented interestingly. & 4 \\
\hline & & The developed media fulfills practical, effective, and efficient functions. & 5 \\
\hline \multirow[t]{4}{*}{2.} & \multirow[t]{4}{*}{ Navigation } & Media can be easily managed. & 5 \\
\hline & & $\begin{array}{l}\text { The layout of the navigation buttons is easy to remember and not too } \\
\text { much. }\end{array}$ & 5 \\
\hline & & The navigation key runs according to function and without obstacles. & 5 \\
\hline & & Navigation buttons are consistent with each display. & 5 \\
\hline \multirow[t]{3}{*}{3.} & \multirow{3}{*}{$\begin{array}{l}\text { Presentation } \\
\text { of Animations } \\
\text { and } \\
\text { Illustrations }\end{array}$} & $\begin{array}{l}\text { Animations, illustrations, and media backgrounds are presented } \\
\text { attractively. }\end{array}$ & 4 \\
\hline & & There is a compatibility between the text and illustrations in the media. & 4 \\
\hline & & $\begin{array}{l}\text { Illustrations can help the presentation of exercises and evaluations in the } \\
\text { media. }\end{array}$ & 5 \\
\hline \multirow[t]{4}{*}{4.} & \multirow{4}{*}{$\begin{array}{l}\text { Use of } \\
\text { language }\end{array}$} & The text used is clear and following EYD. & 4 \\
\hline & & The language used can be spoken and understood & 5 \\
\hline & & The text used in the media uses general terms. & 5 \\
\hline & & Game media instructions are explained precisely. & 4 \\
\hline
\end{tabular}




\section{The following is an analysis of data from the results of the assessment of media experts.}

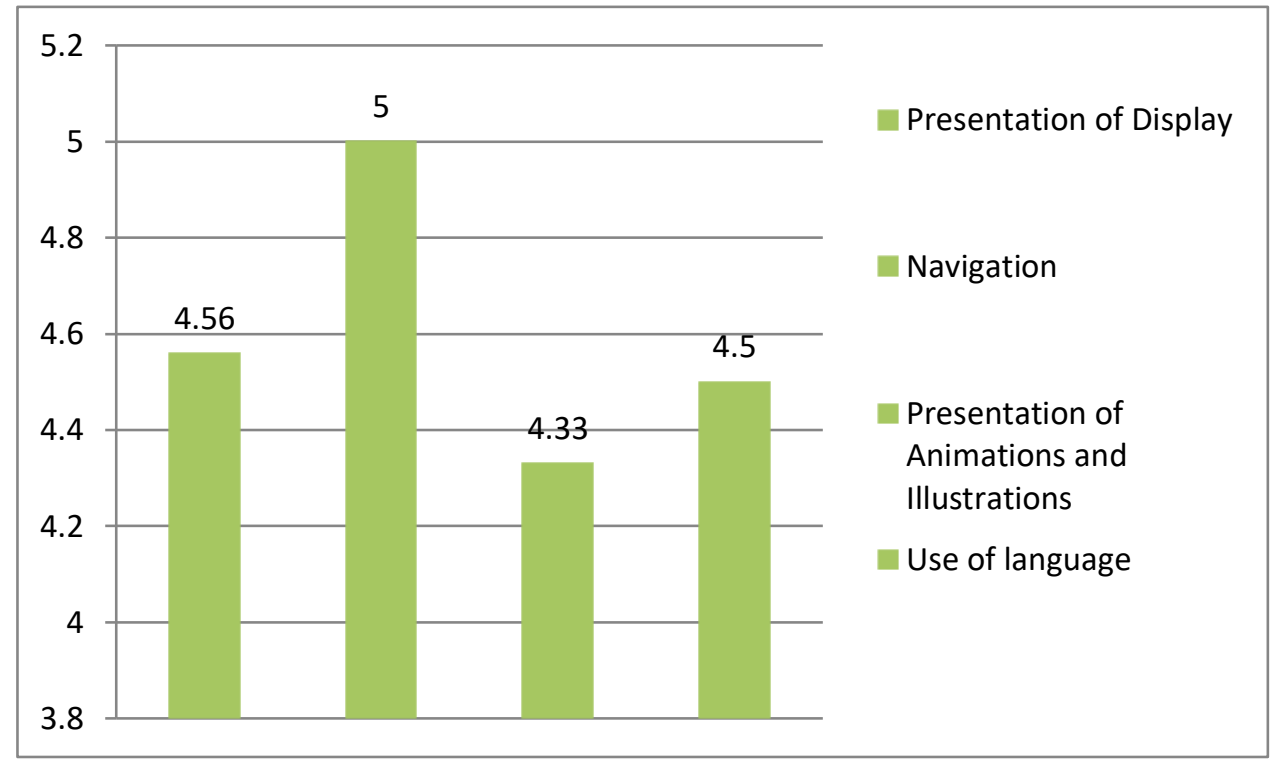

Figure 13. Media Expert Validation Results

Figure 13. shows that the assessment of the media for the navigation aspect gets the highest average score of 5. For the results of the assessment aspects of the display, animation, illustration, and use are also above 4.20. This shows that the developed game media is easy to run by students of grade VII, the use of communicative language, and easy for students to understand, and the design and appearance in the media are also interesting. The average Total Validity (ATV) obtained by the media is 4.6 or $92 \%$ which is in the category of very feasible to use. Based on the assessment by media experts revealed that the media can be suitable for use in learning mathematics in junior high school class VII without the need for revision.

The material expert involved in the expert examination stage was a UNIMOR Mathematics education lecturer. The results of the expert analysis of the media aspects can be seen in Table 5.

Table 5. Results of Expert Validation on Game Education Materials

\begin{tabular}{|c|c|c|c|}
\hline No. & $\begin{array}{l}\text { Evaluated } \\
\text { Aspects }\end{array}$ & Description & Assessment \\
\hline \multirow[t]{6}{*}{1.} & Quality of & The truth of the concept of matter in terms of scientific aspects. & 4 \\
\hline & & $\begin{array}{l}\text { The suitability of the material with Basic Competence and Learning } \\
\text { Objectives. }\end{array}$ & 4 \\
\hline & & $\begin{array}{l}\text { The material and examples presented to support the independence of } \\
\text { student learning. }\end{array}$ & 4 \\
\hline & & $\begin{array}{l}\text { The suitability of the level of difficulty and abstractness of concepts } \\
\text { with the cognitive development of seventh-grade junior high school } \\
\text { students. }\end{array}$ & 4 \\
\hline & & $\begin{array}{l}\text { The clarity in the formulation of examples that can support student } \\
\text { understanding. }\end{array}$ & 4 \\
\hline & & $\begin{array}{l}\text { Learning aspects including cognitive, affective, and psychomotor } \\
\text { have been integrated into the material. }\end{array}$ & 4 \\
\hline \multirow[t]{2}{*}{2.} & $\begin{array}{l}\text { Quality of in- } \\
\text { game question }\end{array}$ & $\begin{array}{l}\text { The suitability of the exercise and evaluation with the material and } \\
\text { learning objectives. }\end{array}$ & 4 \\
\hline & & Evaluation can be used as a test of student learning outcomes. & 3 \\
\hline
\end{tabular}


presentation and evaluation
3. Use of language
Equitable distribution of training and evaluation at each level and evaluation, i.e. easy, medium, and difficult.

The clarity in the formulation of training and evaluation.

Linkages of training and evaluation with

existing conditions in the environment around meant Timor local wisdom.

A variety of exercises and evaluations related to the development of local wisdom.

Conformity between text and illustration.

The information presented is sufficient for students to use in answering questions

The training and evaluation presented in the context were related to the Timor's local wisdom.

The truth is the answer key.

Use of spelling following EYD.

Accuracy in terms of use.

The politeness of the use of language that does not reduce the values of education.

The sentences used in the game are easy to understand.

Language suitability by level student thinking.

Instructions for using educational games

delivered clearly.
4

5

5

3

4

5

5

4

4

3

4

4

In Table 5., it appears that the 4 indicators are stated to be very good on the quality of the presentation of the questions and evaluation exercises, namely the linkages of the exercises and evaluations with the conditions in the environment around the local Timor local wisdom, Variations of training and evaluation related to the development of local wisdom, presented contextual associated with Timor local wisdom, Truth key answers. The following is an analysis of data from the results of the assessment of media experts.

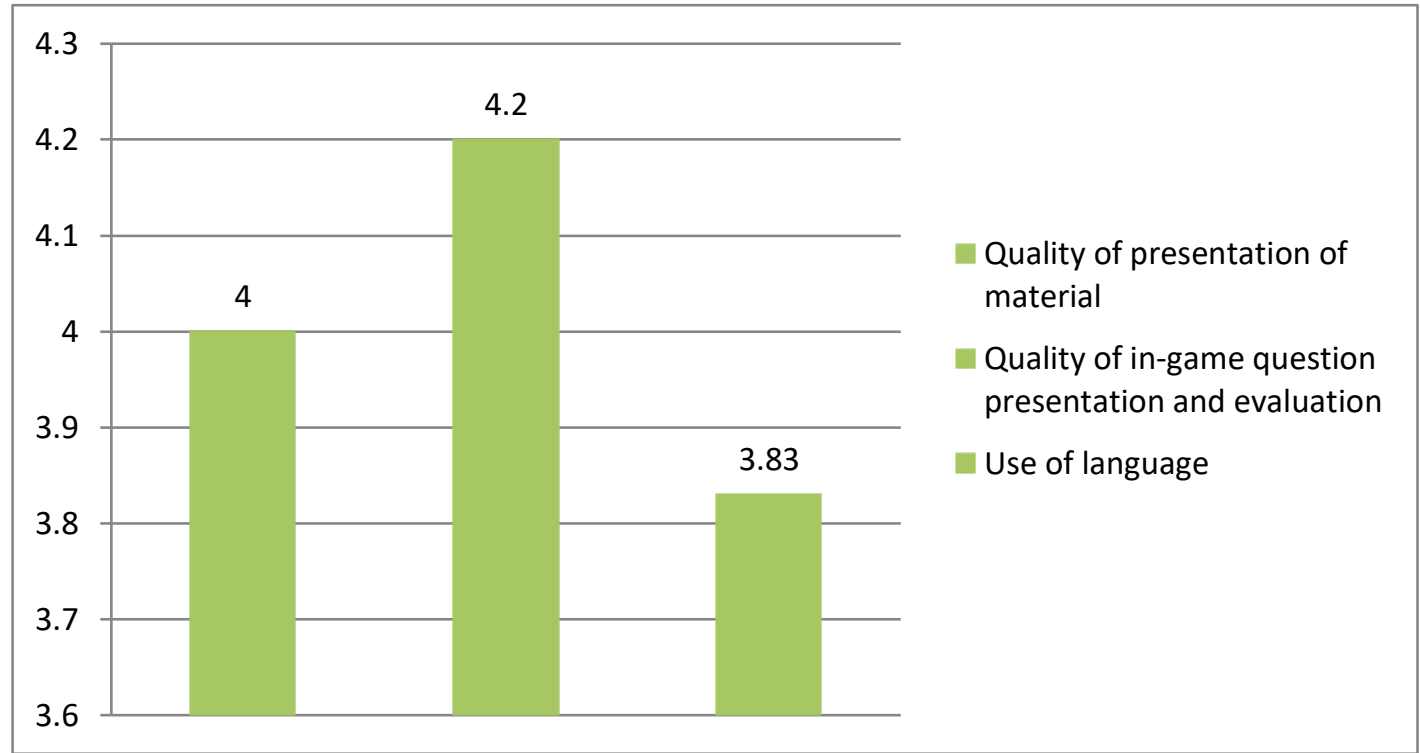

Figure 14. Results of the validation of material experts

Figure 14. presented data from the results of the expert validator's assessment of the material that has been analyzed. The results of the analysis showed that the criteria for presenting the question and evaluation exercises received the highest average score, which was 4.2. With this average value, the criteria for the presentation of the question and evaluation exercises are included in the feasible category. It shows that the information presented in the 
form of animation also helps students in understanding the story questions presented in the media. Questions are presented as attractive as possible and following the level of cognitive development of students. Furthermore, the problems constructed in the media are related to the local culture of the student's environment such as traditional houses, musical instruments, woven cloth, and others. For the quality presentation criteria, the material gets a value of 4 . With the average value, the material quality criteria are included in the feasible category. It shows that the material and sample questions contained in educational game media are easily understood by students. Whereas the criteria for language use get an average value of 3.83 or $76.6 \%$, referred to in the feasible category. It shows that the material expert validator assesses that the use of words in conveying questions into story problems is easily understood by students. The average Total Validity of game media by material experts is 4.01 and based on media validity indicators, the educational game media is in the feasible category. Based on the assessment of the feasibility of the quality of the presentation of exercises and evaluations, the quality of the presentation of the material, and the use of media language to the overall learning strategy, the material expert stated that the game media was appropriate to be used in mathematics learning in seventh grade junior high schools by making some minor revisions to the educational game media.

The user involved in the expert examination stage is a mathematics teacher and two teachers who are implementing PPL. The results of the expert analysis of the media aspects can be seen in Table 6.

Table 6. Teacher Validation Sheets for Media Game Education

\begin{tabular}{|c|c|c|c|}
\hline No. & Evaluated Aspect & Description & Assessment \\
\hline \multirow[t]{5}{*}{1.} & \multirow{5}{*}{$\begin{array}{l}\text { Presentation of } \\
\text { material }\end{array}$} & The truth of the concept of matter in terms of scientific aspects. & 4 \\
\hline & & $\begin{array}{l}\text { Material compatibility with Basic Competency and Objectives } \\
\text { Learning. }\end{array}$ & 4 \\
\hline & & $\begin{array}{l}\text { The material and examples presented to support the independence of } \\
\text { student learning. }\end{array}$ & 5 \\
\hline & & $\begin{array}{l}\text { The suitability of the level of difficulty and abstractness of concepts } \\
\text { with the cognitive development of seventh-grade junior high school } \\
\text { students. }\end{array}$ & 4 \\
\hline & & $\begin{array}{l}\text { The clarity in the formulation of examples that can support student } \\
\text { understanding. }\end{array}$ & 4 \\
\hline \multirow[t]{11}{*}{2.} & \multirow{11}{*}{$\begin{array}{l}\text { Quality and } \\
\text { presentation of } \\
\text { practice questions and } \\
\text { evaluations }\end{array}$} & $\begin{array}{l}\text { The suitability of the exercise and evaluation with the material and } \\
\text { learning objectives. }\end{array}$ & 5 \\
\hline & & Evaluation can be used as a test of student learning outcomes. & 4 \\
\hline & & $\begin{array}{l}\text { Equitable distribution of training and evaluation at each level and } \\
\text { evaluation, i.e. easy, medium, and difficult. }\end{array}$ & 5 \\
\hline & & $\begin{array}{l}\text { The link between training and evaluation with the conditions in the } \\
\text { surrounding environment is meant by the local wisdom of Timor. }\end{array}$ & 5 \\
\hline & & Conformity between text and illustration. & 4 \\
\hline & & $\begin{array}{l}\text { The information presented is sufficient for students to use in } \\
\text { answering questions. }\end{array}$ & 4 \\
\hline & & $\begin{array}{l}\text { The training and evaluation presented in the context were related to } \\
\text { the Timor's local wisdom. }\end{array}$ & 5 \\
\hline & & The balance between text and illustration. & 4 \\
\hline & & The truth is the answer key. & 5 \\
\hline & & The clarity in the formulation of exercises and questions. & 4 \\
\hline & & $\begin{array}{l}\text { Variation of exercises and evaluations related to the development of } \\
\text { local wisdom. }\end{array}$ & 5 \\
\hline \multirow[t]{2}{*}{3.} & \multirow[t]{2}{*}{ Use of language } & Use of spelling following EYD. & 4 \\
\hline & & Accuracy in terms of use. & 5 \\
\hline
\end{tabular}




\begin{tabular}{|c|c|c|c|}
\hline \multirow{9}{*}{4.} & \multirow{9}{*}{$\begin{array}{l}\text { Use and effects of } \\
\text { media in learning }\end{array}$} & $\begin{array}{l}\text { The politeness of the use of language that does not reduce the values } \\
\text { of education. }\end{array}$ & 5 \\
\hline & & The sentences used in the game are easy to understand. & 4 \\
\hline & & Suitability of language with students' level of thinking. & 4 \\
\hline & & Directions for using educational games are clearly stated. & 4 \\
\hline & & $\begin{array}{l}\text { Students are easy to use and operate the media in the learning } \\
\text { process both independently and in the classroom. }\end{array}$ & 4 \\
\hline & & Educational game media support students to learn independently. & 5 \\
\hline & & $\begin{array}{l}\text { With games, media can attract students' interest and motivation to } \\
\text { take part in learning mathematics. }\end{array}$ & 5 \\
\hline & & Ease of media to understand the material presented. & 4 \\
\hline & & $\begin{array}{l}\text { Through games, media can add information and broaden students' } \\
\text { insights. }\end{array}$ & 5 \\
\hline
\end{tabular}

The following is an analysis of data on the results of evaluations for Grade VII Middle School teachers as media users.

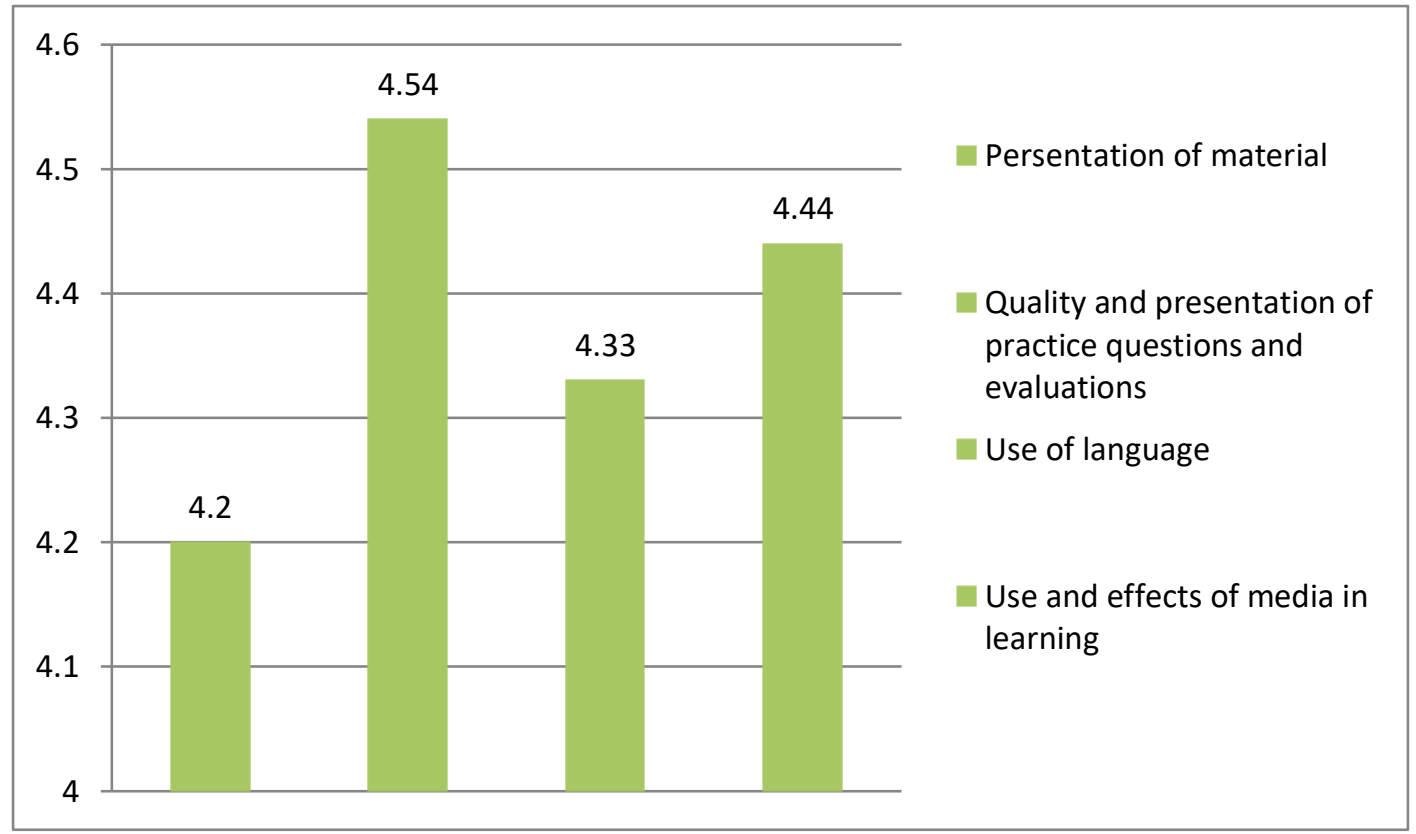

Figure 15. Validation results by users

In Figure 15., the presentation of data about the assessment of media by the user (in this case the teacher) shows that the usage criteria get an average value of 4.44 or $88.8 \%$. With this average value, the usage criteria are included in the very feasible category. This shows that the expert validator of the user considers that game education can be used very easily. For the quality aspect of the presentation of the material get a value of 4.2 which has a decent category. While the quality of the presentation of questions and evaluation exercises, language, use, and effects of media in learning each scored above 4.2, where all three aspects are in the very feasible category.

In general, the assessment shows that the material and questions contained in the constructed education game are following the learning objectives in school by considering the ability of students. The questions presented also have clear information that will make students more creative and independent in solving problems. The existence of animation on the media is also expected to motivate students to be active in learning mathematics. Based on this analysis, it can be concluded that the development of educational games as a medium for 
learning mathematics in class VII MTs Nurul Falah according to the validator has a percentage of more than $75 \%$ or with a total average of $\mathrm{d} 4.33$ with a valid category to be implemented in class VII students with or without improvement.

\section{The Validity of Educational Games as Learning Media based on Trials}

The next step after validation was implementation. The implementation phase in this study was only done in the form of limited trials or commonly said to be small class trials to assess the practicality of the media, whereas field trials in large classes to assess the effectiveness of the media could not be carried out due to the limitations of the researchers' conditions because the school where the study was approaching the holidays.

A limited trial was conducted at MTs Nurul Falah, Kefamenanu for one week from 24 June to 6 July 2020 using WAG (Whatsapp Group) and Google Form because students were carrying out study from home (SFH). In this trial, the researcher was assisted by two mathematics education study program students during the research process, who happened to be carrying out a Field Experience Program (PPL) in class VII and acted as a teacher as well as a guide to the use of game education media. Subjects used as a small class trial are seventhgrade students of SMP with a total of six students with the selection of subjects based on students' abilities. The considerations carried out are assisted by subject teachers by selecting high, medium, and low ability students, each with a total of two students.

Tuesday, June 18 researchers were assisted by two students to create a WAG testing a game education media. Then with the help of students, the six selected students were put in WA groups. The research team then uploaded the game education media. Furthermore, at 09.00 WITA, researchers with the help of students conditioned all research subjects to download the game education application that was uploaded. The first day of the study was approximately 90 minutes. The first ten minutes were used by the research team to direct how to install the application. The next fifteen minutes were used by researchers to explain the purpose of the study and some directions on how to use media containing material and games to students. After that, researchers invited students to use game media independently from June 24 to July 1, 2020. During the process of using media, especially in the game menu, students showed enthusiasm by giving some positive comments and some were asking questions related to the practice questions on the game menu in the WA group chat column. Starting from Thursday, July 2 to Monday, July 6, 2020, the research team distributed Google form links to be filled in by research subjects to see students' responses to the use of game education as a medium for learning mathematics. The following are the results of students' responses to the use of game education media in Table 7.

Table 7. Student Response Questionnaire on the Use of Media Game Education

\begin{tabular}{llc}
\hline No. & \multicolumn{1}{c}{ Evaluated Aspect } & Assessment \\
\hline 1. & $\begin{array}{l}\text { Students can easily read text/writing in the media. } \\
\text { 2. }\end{array}$ & $100 \%$ \\
& $\begin{array}{l}\text { The images presented make it easier for students to understand the } \\
\text { material. }\end{array}$ & $100 \%$ \\
3. & The material presented in-game media is easy to understand. & $100 \%$ \\
4. & $\begin{array}{l}\text { For example, the question and evaluation exercises presented in the game } \\
\text { are quite clear. }\end{array}$ & $100 \%$ \\
5. & The flow of material can be easily understood through the use of language. \\
6. & The material in the media is presented in order and interesting to understand. & $100 \%$ \\
7. & Game media can be a suggestion for learning to be more independent. & $100 \%$ \\
\hline
\end{tabular}




\begin{tabular}{lll}
\hline 8. & Game media can increase student motivation in learning material in terms & $100 \%$ \\
9. & Game media can be used anytime and anywhere. & $100 \%$ \\
10. & Game media can provide additional knowledge. & $100 \%$ \\
11. & The media can broaden students' insights. & $100 \%$ \\
12. & Game media can encourage students' curiosity. & $100 \%$ \\
13. & The character design presented in the game is quite interesting. & $100 \%$ \\
14. & The instructions for using the game are available. & $100 \%$ \\
15. & The game presented makes students challenged. & $85 \%$ \\
\hline
\end{tabular}

The practicality of the learning media can be known based on filling in the student response questionnaire. Table 7. it appears that the frequency of students who choose the "Yes or Agree" option is far more than the frequency of students who choose the "Disagree" option. This is also evident from the 14 statement items, the average response of learning to use media in the "Agree" option is $100 \%$, while the "Disagree" option is only $85 \%$. From these results, it appears that the majority of students approve and respond well to learning using the education game media. Overall the average response of students to the use of game education as a medium for learning mathematics is $98.93 \%$. So, it can be concluded that the response of students to the learning media of Android-based game education with the theme of local culture Timor is very enthusiastic (positive response). This shows that the learning media developed are practical and can provide students' interest and motivation in the mathematics learning process compared to learning that has been implemented in schools, namely traditional methods. These results are in line with research conducted (Chao et al., 2018; Fabian et al., 2018; Qolbi, et al., 2019; Widjayanti et al., 2019).

It was revealed that the existence of digital learning media can increase the interest of school children to learn mathematics, especially school children with low achievement. Furthermore, by presenting the contextual questions related to the student's own culture, it makes learning not only interesting but also more meaningful. So that students can easily understand and carry out the steps to solve problems in the media. Also note that this educational game application works well on Android phones with a minimum operating system version 4.2.2 (Jelly bean), and can be played offline by students. This makes it easier for students to access material without being limited by time and space. Based on the se findings, this development in the future may be able to create new education following current technological developments. One of them is by using a mobile device so that it can help facilitate learning to achieve learning goals.

\section{CONCLUSIONS}

This research had been carried out procedurally by taking into account the existing stages. Based on the research that has been done and referring to the research objectives, an Androidbased learning media for Class VII Middle School students in this research was carried out in stages: determining the potential and problems that will be used as background and problem formulation, collecting data through observation and questionnaires, designing educational games, validating design, revise designs, and test products. Also, mathematics educational game media was appropriate as mathematics learning media for Grade VII Middle School students developed which was declared feasible with a mean validation score of 4.33 based on media experts, material experts, and users. Furthermore, Educational game media were 
practical in that they can provide positive responses based on the results of questionnaire analysis given to students who got a percentage of $98.93 \%$.

Also, making learning media in the form of an Android-based educational game with geometric materials based on local wisdom for seventh-grade junior high school students produced a product in the form of Android-based mathematics learning application with a minimum operating system version 4.2.2 (Jelly Bean). Through game-based learning media integrated into this Android, students can learn independently whenever and wherever. Thus, students can improve their abilities.

Learning media that have been made are limited to the cognitive sphere (color recognition). Therefore, there is a need for further development in the cognitive domain of other learning. Besides, additional material from the learning media that has been produced is needed. The work that needs to be continued is to do a study to see the effectiveness of media use and improvement of student learning outcomes (N-gain).

\section{AUTHOR CONTRIBUTIONS STATEMENT}

This article was conceptualized and original written by SS. YN participated in the methodology, validation and data curation. For review and editing carried out by all authors.

\section{REFERENCES}

Adiwijaya, M., S, K. I., \& Christyono, Y. (2015). Perancangan game edukasi platform belajar matematika berbasis android menggunakan construct 2. TRANSIENT, 4(1), 128-133.

Agustin, R., \& Ambarawati, M. (2019). Mathematics encyclopedia media as android based learning. International Journal of Scientific \& Technology Research, 8(09), 1-4.

Alqahtani, M., \& Mohammad, H. (2015). Mobile applications' impact on student performance and satisfaction. TOJET: The Turkish Online Journal of Educational Technology, 14(4), $102-112$.

Chao, W., Yang, C., Hsien, S., \& Chang, R. (2018). Using mobile apps to support effective game-based learning in the mathematics classroom. International Journal of Information and Education Technology, 8(5), 354-357.

Dasmo, Astuti, I. A. D., \& Nurullaeli. (2017). Pengembangan pocket mobile learning berbasis android. JRKPF UAD, 4(80), 71-77.

Drigas, A. S., \& Pappas, M. A. (2015). A review of mobile learning applications for mathematics. IJIM, 9(3), 18-23.

Fabian, K., Topping, K. J., \& Barron, I. G. (2018). Using mobile technologies for mathematics : effects on student attitudes and achievement. Educational Technology Research and Development, 66(5), 1119-1139.

Ferdianto, F., \& Setiyani. (2018). Pengembangan bahan ajar media pembelajaran berbasis kearifan lokal. JNPM (Jurnal Nasional Pendidikan Matematika), 2(1), 37-47. 
Figueiredo, M., Godejord, B., \& Rodrigues, J. (2016). The development of an interactive mathematics app for mobile learning. 12th International Conference Mobile Learning, 75-81.

Hiebert, J., \& Grouws, D. A. (2007). The effects of classroom mathematics teaching on students' learning, Second handbook of research on mathematics teaching ang learning.

Mullis, I. V. S., Martin, M. O., Foy, P., \& Hooper, M. (2015). TIMSS 2015 international results in mathematics. . Chestnutt Hill: TIMSS \& PIRLS International Study Center.

OECD. (2019). PISA 2018 results combined executive summaries volume I, II \& III.

Pons-Llinares, J., Pérez, S. B., \& Bonet, J. (2019). Development of an e-learning platform for improving and assesing the student outcomes in electrical engineering. Spain: IATED.

Purwanto, M. N. (2012). Prinsip-prinsip dan teknik evaluasi pengajaran. Bandung: Remaja Rosdakarya.

Qolbi, M. S., Thaariq, Z. Z. A., Az-Zahroh, S. F., Anwar, M. M., \& Faiza, N. (2019). Design and development of game based learning applications for mathematics learning based on multiple language to develop verbal capabilities. Jurnal Pendidikan Dan Pembelajaran, 26(2), 51-56.

Rahadi, M. R., Satoto, K. I., \& Windasari, I. P. (2016). Perancangan game math adventure sebagai media pembelajaran matematika berbasis android. Jurnal Teknologi Dan Sistem Komputer, 4(1), 44-49.

Setyaningrum, W., \& Waryanto, N. H. (2018). Developing mathematics edutainment media for android based on students ' understanding and interest : A teachers 'review Developing mathematics edutainment media for Android based on students 'understanding and interest: A teachers 'review. IOP Publishing.

Skillen, M. A. (2015). Mobile learning: Impacts on mathematics education. Proceedings of the 20th Asian Technology Conference in Mathematics, 205-214. Leshan, China.

Sung, Y., Chang, K., \& Liu, T. (2016). Computers \& Education The effects of integrating mobile devices with teaching and learning on students' learning performance: A metaanalysis and research synthesis. Computers \& Education, 94, 252-275.

Taleb, Z., Ahmadi, A., \& Musavi, M. (2015). The effect of m-learning on mathematics learning. Procedia - Social and Behavioral Sciences, 171, 83-89.

Vitianingsih, A. V. (2016). Game edukasi sebagai media pembelajaran pendidikan anak usia dini. INFORM, 1(1), 1-8.

Vlachopoulos, D., \& Makri, A. (2017). The effect of games and simulations on higher education: A systematic literature review.

Widjayanti, W. R., Masfingatin, T., \& Setyansah, R. K. (2019). Media pembelajaran interaktif berbasis animasi pada materi statistika untuk siswa kelas 7 SMP. Jurnal Pendidikan Matematia, 13(1), 101-112. 
Suddin, S., \& Deda, Y. N.

Widoyoko, E. P. (2009). Evaluasi Program Pembelajaran. Yogyakarta: Pustaka Pelajar.

Yulia, \& Silalahi, M. (2019). Perancangan game matematika sebagai media pembelajaran berbasis android. Innovation in Research of Informatics (INNOVATICS), 1(2), 78-85. 